\title{
FIELD PERSISTENCE OF BACILLUS THURINGIENSIS ON MAIZE LEAVES (ZEA MAYS L.)
}

\author{
Marinéia de Lara Haddad*; Ricardo Antonio Polanczyk; Sergio Batista Alves; Marcelo de Oliveira Garcia \\ Departamento de Entomologia, Fitopatologia e Zoologia Agrícola, Escola Superior de Agricultura Luiz de Queiroz, \\ Universidade de São Paulo, Piracicaba, SP, Brasil
}

Submitted: June 05, 2003; Approved: October 04, 2005

\begin{abstract}
The persistence slope of Bacillus thuringiensis $(B t)$ based products in the field is an important parameter to evaluate their efficacy. The half-life, estimated based on persistence slope parameters, is one of the most effective tools to select microbial pesticides. The aim of this research was to study the relationship between viability loss of $B t$ spores on maize leaves and their concentration, comparing it with field persistence. The experimental design was split-plot on time, composed by maize plants, in which three concentrations (half, normal and double doses) of a Dipel commercial formulation were applied. In each plot three leaves in the upper part of three plants where randomly selected. Samples of these leaves were collected 3 to 72 hours after treatment, to count the number of viable spores in two foliar dishes with 1 $\mathrm{cm}$ in diameter. The field persistence was determined using an exponential model, linearized by a logarithmic transformation of viable spores number in time. Using the log linear method of confidence intervals, there were no significantly differences $(\mathrm{P}=0.05)$ in half-lifes: 18.2 hours for half-dose, 16.5 hours for normal dose and 13.6 hours for double dose. Assuming a fictitious index of insect consumption equal to one, the effective doses according to concentrations were calculated. It was verified that $77 \%, 78 \%$ and $80.5 \%$ of the effective doses (viable spores) remained on the leaf surface after the first day of treatment, respectively.
\end{abstract}

Key words: entomopathogen, Dipel, maize leaves, Bacillus thuringiensis, field persistence

\section{INTRODUCTION}

Cereals are seeds of plants, usually members of the grass family but there are a few exceptions. They are planted through the year, out mainly at the end of the summer. When the seeds ripe, they die down. Like all seeds, cereals are very nutritious because they contain all the nutrients the embryo plant needs to start growing. Unrefined cereals are valuable sources of proteins, carbohydrates, B vitamins and also contain some fat, iron, vitamin $\mathrm{E}$ and trace minerals. They are a very good source of fibre in the diet as well. Some cereals (wheat, barley, rye and oat) contain the protein gluten, which is essential for leavened bread-making. Maize (Zea mays) is the principal food plant of
America and was unknown in other parts of the world until Columbus reached America in 1492. Initially grown by the Maya, Inca and Aztec civilizations, and by various North American Indian tribes, mayze has spread to Canada, Soviet Union, Italy, Spain, Egypt, India and South Africa. Maize is used for human food, animal feed and as a source of raw materials for industry (8).

One of the most important factors that limits the worldwide production of maize is the occurrence of pests. The fall armyworm (Spodoptera frugiperda) is the main pest and causes significant production losses in Brazil (6). Nowadays, there are many attempts to reduce the use of chemicals to control this pest. One alternative is the utilization of entomopathogenic bacteria.

*Corresponding Author. Mailing address: Departamento de Entomologia, Fitopatologia e Zoologia Agrícola - ESALQ/USP, Caixa Posta 9. 13418-900, Piracicaba, SP, Brasil. E-mail: mlhaddad@esalq.usp.br 
The low field persistence of Bacillus thuringiensis (Bt)products due to ultraviolet radiation is one of the most important factors in reducing their utilization in pest control. It is well known that besides environmental factors and host plant, the loss of viable spores may be related to formulation concentration. Also related to Bt efficiency is the direct impact that microorganism populations cause in an insect population. The determination of field persistence formulations is one tool to evaluate the effect of $B t$ viable spores. The parameter halflife, based on persistence slope, is one of the most important to select a microbial pesticide.

Some works show that, using the number of viable spores it is possible to calculate the persistence and effective dose of $B t$ formulations in several environmental conditions $(12,13,14)$. According to Pinnock et al. (15), effective dose is the quantity of viable spores consumed by the insect at larval stage, that is, quantity of viable spores available to pest population. The effective dose can be estimated by using the persistence slope and the pest consumption index $(15,16)$. These parameters were shown to be effective to estimated the $B t$ effective dose. Also, to study the modeling of host/pathogen systems, aiming evaluation of control strategies, it is necessary to know the persistence of the pathogen in the field, the index of pest consumption and mortality, and the mathematical model, deterministic or esthocastic, that represents the insect mortality $\mathrm{x}$ pathogen dose function. The objective of this research was to study the relationship between spore loss viability on maize leaves and the persistence and effective dose in the field.

\section{MATERIALS AND METHODS}

The experimental design of slipt-plot on time in randomized blocks was conducted at the experimental area of the "Departamento de Entomologia, Fitopatologia e Zoologia Agrícola" (Escola Superior de Agricultura Luiz de Queiroz, University of São Paulo, Brazil). The climatic conditions during the experimental period, expressed in mean values, were $19.5^{\circ} \mathrm{C}$, $82.2 \mathrm{RH}$, wind speed of $1.1 \mathrm{~ms}^{-1}$, nill rainfall and global radiation $14.62 \mathrm{MJ} \mathrm{m}^{-2}$. The daily data were provided by an Automatic Metereologic Station ("Departamento de Física e Metereologia" - ESALQ/USP) at $22^{\circ} 42^{\prime} 30^{\prime \prime} \mathrm{S}, 47^{\circ} 38^{\prime} 00^{\prime \prime} \mathrm{W}$ and $546 \mathrm{~m}$ of altitude.

The product used was Dipel in the recommended concentration, half recommended concentration, and 2-fold recommended concentration. The number of viable spores in the product determined in laboratory according to Alves and Moraes (1) was 560 millions $\mathrm{mL}^{-1}$.

The suspensions were applied on 45 maize plants (Zea mays L.) between development stages v3 and v4 (11), using a $\mathrm{CO}_{2}$ sprayer. In each treatment three plants were randomly chosen, and six leaves in the upper part of plants (without shading, and with similar leaf axis and leaf orientation) were selected. Three leaves were kept in a Biological Oxygen Demand chamber under UV light $\left(25 \pm 2^{\circ} \mathrm{C}\right.$ and $\left.70 \pm 10 \mathrm{RH}\right)$ and the other three remained in the plant (controls). In each leaf evaluations were done $3 \mathrm{~h}$, $8 \mathrm{~h}, 27 \mathrm{~h}, 32 \mathrm{~h}, 51 \mathrm{~h}, 56 \mathrm{~h}$ and $72 \mathrm{~h}$ after application of the product, removing 2 disks with $1 \mathrm{~cm}$ in diameter from each leaf (test and control) (Fig. 1).

A total of 252 disks were obtained. Each disk was transferred to a glass tube containing $10 \mathrm{~mL}$ of distilled water and shaked during one minute. Afterwards, $1 \mathrm{~mL}$ was removed and submitted to termic shock $\left(80^{\circ} \mathrm{C}\right.$ and $-10^{\circ} \mathrm{C}, 10$ minutes and 3 minutes, respectively) to eliminate contaminants and undesirable microorganisms. Then, $5 \mu \mathrm{L}$ were dropped in 5 spots on a plastic Petri dish $10 \mathrm{~cm}$ in diameter, containing nutrient medium $(0.15 \%$ agar, $0.5 \%$ yeast and $0.17 \mathrm{M} \mathrm{NaCl}$ ), for bacterial growth until 48 hours. The number of $B t$ colonies in each point was recorded and the numbers of viable spores was determined according to Alves and Moraes (1).

To determine the persistence or half-life $(\pi)$ two mathematic models (simple linear and segmented linear) were tested. The linear model was obtained from exponential: $\mathrm{Y}_{\mathrm{ik}}=\mathrm{a}^{*} \operatorname{EXP}\left(\mathrm{b}^{*} \mathrm{Z}_{\mathrm{ik}}\right)$ $* e_{i}$, where $Y_{i k}=$ number of viable spores in the leave $i$ and in the sample $\mathrm{k} ; Z_{\mathrm{ik}}=$ time (hours) in which the leave $\mathrm{i}$ was collected in the sample $\mathrm{K} ; \mathrm{a}=$ number of viable spores after treatment application; $b=$ velocity of spores inactivation and $e_{i}=$ experimental error $\cap \mathrm{N}\left(0, \delta^{2}\right)$. The exponential model was submitted to a logarithmic anamorfosis, using the method of maximum likelihood to obtain the parameters estimatives. Due to this transformation, the counts of viable spores equal to zero were replaced for $0.5 /$ number of replications. Also the equal counts observed at the same time were considered as one point, to avoid grouping of graphic representations.

The half-life parameter $(\pi)$, usually used for microbial insecticide selection, was determined according to Pinnock et al. (12), and obtained by $\pi=\log (0.5) / b$ (hours). For $\pi$ comparisons, the overlap method of confidence intervals was utilized ( $\mathrm{P}=$ 0.05 ). For determination of $\pi$ by linearized segmented exponential

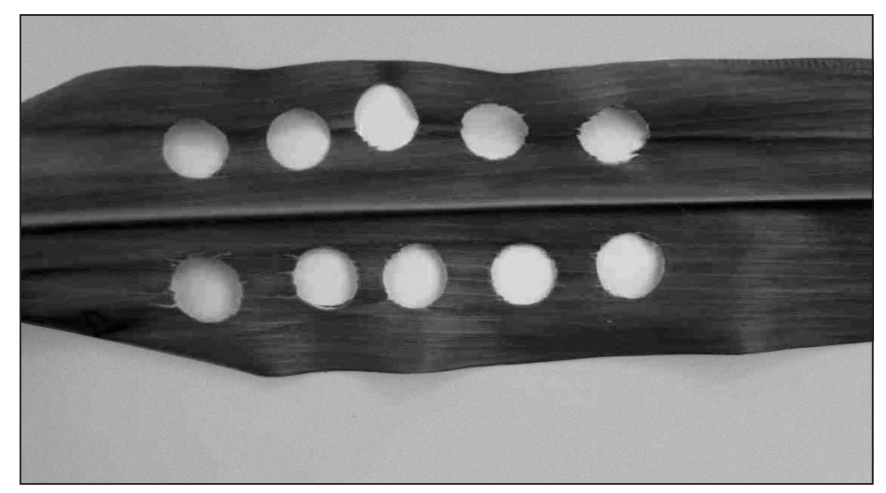

Figure 1. Maize leave sampled in the first five evaluations. 
model $\log \left(Y_{i}\right)=a+b_{e} * X_{1}+b_{1} * X_{2}$, where: $Y_{i}=$ number of viable spores; $b_{e}, b_{1}=$ parameters, the same methodology was used, in addition to the following considerations:

$\mathrm{X}_{1}=$ first linear segment (before breakpoint $(\mathrm{BK}) ; \mathrm{X}_{2}=$ second linear segment (after BK).

The vectors, $\mathrm{X}_{1}$ and $\mathrm{X}_{2}$, transposed, are given by: $\mathrm{X}^{\mathrm{T}}{ }_{1}=(0.5$, $1,2, \ldots, \mathrm{BK}, \ldots, \mathrm{BK}) ; \mathrm{X}^{\mathrm{T}}{ }_{2}=(0,0,0, \ldots 1, \ldots, \mathrm{k}) ; \mathrm{k}=$ number of samples. The effective dose (L) in time $(0-\mathrm{T})$, according to Brand et al. (3), is given by: $\mathrm{L}=\log (\mathrm{r})-0.363+\mathrm{A}$, where $: \mathrm{L}=\log ($ dose $)$ viable spores; $r=$ pest index consumption, assumed equal to 1 to a ficticious insect and

$$
\mathrm{A}=\mathrm{a}+\log _{10}\left[\frac{1-10 \mathrm{~b}_{\mathrm{e}} \mathrm{T}_{\mathrm{B}}}{-\mathrm{b}_{\mathrm{e}}}+\frac{10^{\mathrm{b}_{1} \mathrm{~T}_{\mathrm{B}}-\mathrm{b}_{\mathrm{e}} \mathrm{T}}}{-\mathrm{b}_{1}}\right]
$$

where: $T_{B}=B K=$ segmented regression breakpoint; $T=$ total period of evaluation ( $\pi$ hours); $a=$ intercept in time $T=0 ; b_{e}$, $\mathrm{b}_{1}=$ parameters for segmented regression. Also was used an approach to A, expressed by: $A=a-\log \left(-b_{e}\right)$, for the segmented model and $A=a-\log (-b)$, for the simplest one. The number of viable spores data were submitted to variance analyses, with the medium of factors dose and time submitted to Tukey Test $(\mathrm{P} \leq 0.05)$ and polynomial regression (fourth degree), respectively.

\section{RESULTS AND DISCUSSION}

The variance analyses of viable spores number on maize leaves showed a significant interaction between Dipel doses and time of application. The detailing of this interaction, by Tukey Test $(\mathrm{P} \leq 0.05)$, showed that the number of viable spores, in the double dose, was statiscally superior to the other doses, at 3, 8, 27 and 51 hours after application. The number of viable spores at half-dose and dose did not show significant

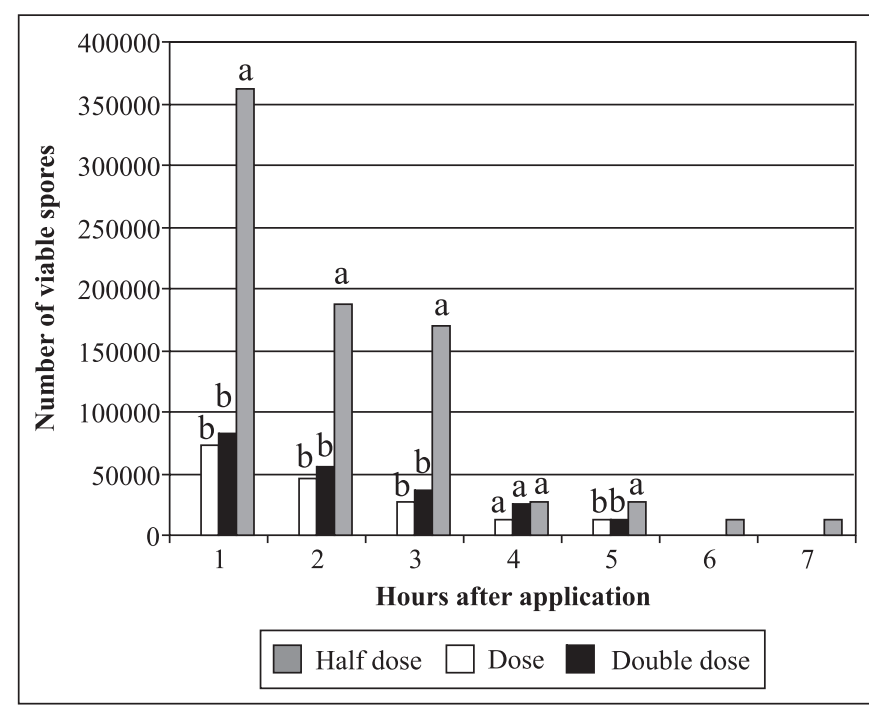

Figure 2. Average number of Bacillus thuringiensis viable spores $\left(\mathrm{mL}^{-1}\right)$ on maize leaves after Dipel application.

differences until 51 hours after application, but after that only in the double dose the presence of viabel spores was observed (Fig. 2). The persistence and half-life $(\pi)$, tested using simple and segmented linear models (Table 1), presented high significance. Thus the simple linear model was selected Table 1 also shows the intercepts in time zero $(\log$ a). Such values are estimatives of the average number of viable $B t$ spores immediately after treatment and the values of slope (b) indicate the velocity of spore fixation in the leaf. Althought in the doble dose a higher number of spores was observed immediately after application, the velocity of spore fixation in the leave was lower than in half-dose and dose (Table 1).

Table 1. Statistics and estimatives of parameters of the matemathic model fitted to study the persistence of Bacillus thuringiensis viable spores on maize leaves in the field, after application of different doses of Dipel.

\begin{tabular}{|c|c|c|c|c|c|c|}
\hline \multirow[t]{2}{*}{ Dipel } & \multicolumn{2}{|c|}{$\begin{array}{l}\text { F Statistics and Level } \\
\text { of significance }\end{array}$} & \multicolumn{4}{|c|}{ Estimatives of parameters } \\
\hline & $\begin{array}{c}{ }^{*} \text { Linear model } \\
\text { model }\end{array}$ & Linear segmented & $\begin{array}{l}\text { Intercept } \\
\log (a)\end{array}$ & Slope (b) & $\begin{array}{l}\text { Persistence or } \\
\text { half-life }(\pi) \text { hours }\end{array}$ & $\begin{array}{l}\text { Confidence interval } \\
\text { for } \pi(\mathrm{P}=0.05)\end{array}$ \\
\hline \multirow[t]{2}{*}{ Half dose } & $\mathrm{F}=19.05$ & $\mathrm{~F}=18.12$ & & & & \\
\hline & $\mathrm{P} \leq 0.03$ & $\mathrm{P} \leq 0.04$ & 4.7919 & -0.0164 & $18.4 \mathrm{a}$ & $10.67-66.89$ \\
\hline \multirow[t]{2}{*}{ Dose } & $\mathrm{F}=17.85$ & $\mathrm{~F}=16.54$ & & & & \\
\hline & $\mathrm{P} \leq 0.03$ & $\mathrm{P} \leq 0.03$ & 4.8459 & -0.0182 & $16.5 \mathrm{a}$ & $10.06-70.01$ \\
\hline \multirow[t]{2}{*}{ Double dose } & $\mathrm{F}=29.41$ & $\mathrm{~F}=31.10$ & & & & \\
\hline & $\mathrm{P} \leq 0.01$ & $\mathrm{P} \leq 0.01$ & 5.4154 & -0.1221 & $13.6 \mathrm{a}$ & $9.23-26.02$ \\
\hline
\end{tabular}

* For all doses, the linear simple model was used $(\mathrm{P} \leq 0.05)$. Persistence values, followed by the same letter, are statiscally similar $(\mathrm{P}=0.05)$. 
Studies carried out by Pinnock et al. $(12,13)$, with different formulations of $B t$ and different plants, showed the importance, of the method of spores isolation in the substrate for an optimal estimative of parameter a and the importance of the differences obtained in parameter $b$, due to differences in species studied, in the same environment. Using a combination of this parameters, the solution of equity $10^{\mathrm{a}} 10^{\mathrm{b}(t+\pi)}=(0.5) 10^{\mathrm{a}} 10^{\mathrm{bt}}$, that is, $\pi=\log (0.5) / \mathrm{b}$ is called half-time in the field. By this equity, it is possible to verify that $\pi$ means the time in which $50 \%$ of spore population of $B t$ remain viable in the substrate. The $\pi$ value plus the confidence interval and the mathematic representation, according to the Dipel dose, are given in Table 1 and Fig. 1, respectivelly. Averages of repetitions were used in the mathematic representation of persistence. In maize leaves, the persistences were 18.4, 16.5 and 13.6 hours for half-dose, dose and double dose, respectively. These values did not show significant differences $(P=0.05)$, although the number of viable spores in double dose was superior to other ones after 3, 8, 27 and 51 hours of application (Table 1 and Fig. 2). The comparison between persistences was done by the confidence intervals, showing that variation, in half dose and dose was more extensive if compared to double dose (Table 1). An increase in the number of foliar dishes is suggested because some of them showed no viable spores. The occurence of a high number of leaf disks without viable spores may explain of the similarity among the values of viable spores in the studied doses.

Dipel seems to have one or more intrinsic characteristics that allow a higher initial spore viability that decreases significantly afterwards (Fig. 2). Also, this product has one or more characteristics that help to maintain the persistence of spores, despite their low number (Table 2 and Fig. 3). According to Couch and Ignoffo (4) and Batista Filho et al. (2), the presence of additives, such as solar protectors and evaporation retardants in the products improved the desired physical properties (ability to flow, wet, disperse and suspend) of agricultural $B t$

Table 2. Effective dose (L), available dose in the first day $\left(\mathrm{L}_{1}\right)$ and percentage of viable spores on maize leaves after the first day of Dipel application.

\begin{tabular}{lccc}
\hline Dipel & $\begin{array}{c}\text { Effective dose } \\
\text { (viable spores) } \\
(\mathrm{L})^{1}\end{array}$ & $\begin{array}{c}\text { Available dose } \\
(\text { viable spores) } \\
\left(\mathrm{L}_{1}\right)^{2}\end{array}$ & $\begin{array}{c}\text { Percentage of } \\
\text { viable spores } \\
\text { in the leaf } \\
\left(\mathrm{L}_{1} \mathrm{~L} * 100\right)\end{array}$ \\
\hline Half dose & 6.21 & 4.79 & 77 \\
Dose & 6.22 & 4.83 & 78 \\
Double dose & 6.71 & 5.40 & 80.5 \\
\hline
\end{tabular}

${ }^{1} \mathrm{~L}=\log (\mathrm{r})-0.363+\mathrm{a}-\log (-\mathrm{b})$, were $\mathrm{r}=$ index of insect consumption; ${ }^{2} \mathrm{~L}_{1}=\mathrm{L}+\log \left(1-10^{\mathrm{b}}\right)$.
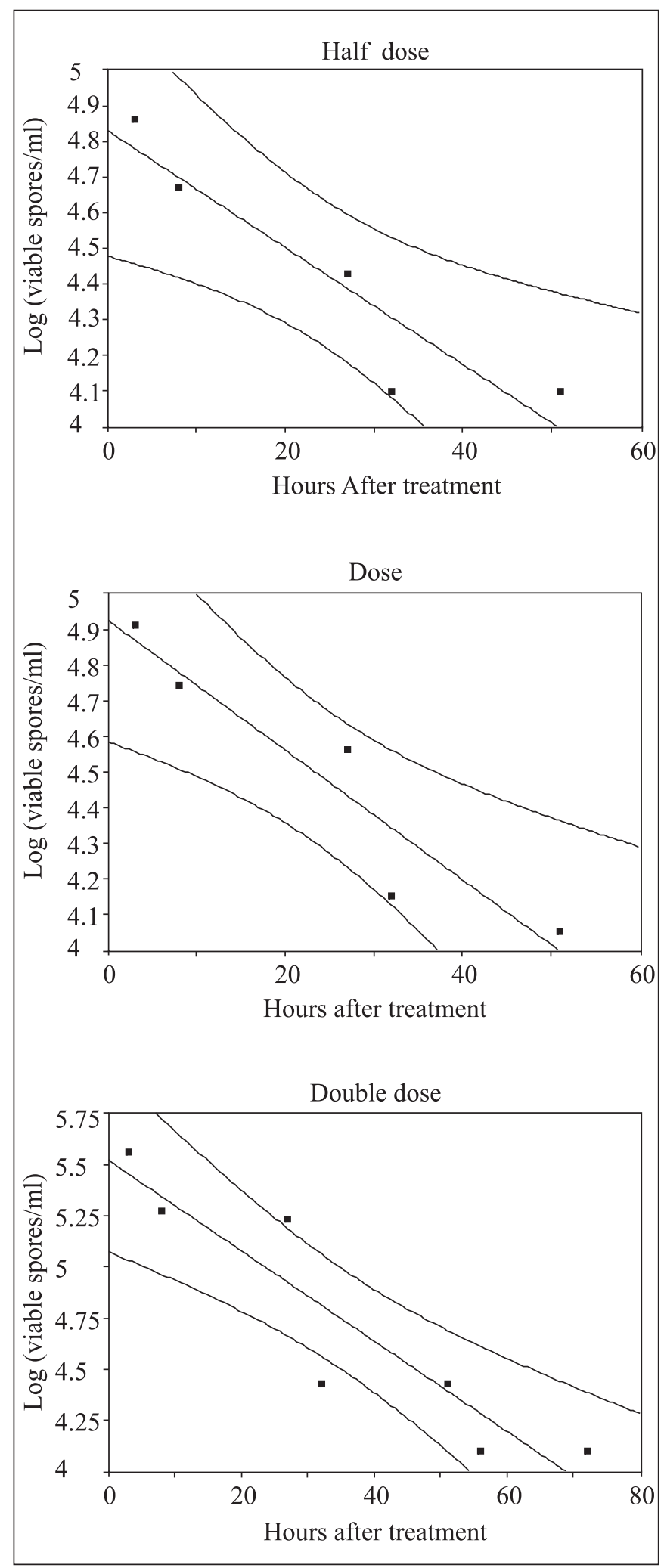

Figure 3. Persistence of Bacillus thuringiensis viable spores on maize leaves in the field. 
formulations. In earlies days, like in the 80 's, it was almost impossible to wet the powder, leading to erroneuos results in the field (4).

Althought some advances were obtained on biopesticides formulation, their persistence was still lower than desired. An intensive research was conducted aiming to get new formulations able to result in higher persistence and more efficiency against pests. So, some attempts were made to encapsulate $B t$ kurstaki toxins $(5,9,10)$, resulting in a higher persistence in cotton leaves cultivated at greenhouse (above two weeks) and also in higher efficiency against certain pest, such as Ostrinia nubilalis (7).

These researches advanced and in 1990's a new biopesticide called $\mathrm{MVP}^{\circledR}$ became available to the farmers. This product is based on a CellCap ${ }^{\circledast}$ system to protect the active ingredient. $\mathrm{MVP}^{\circledast}$ has higher persistence and activity against pests than other formulations due to presence of Pseudomonas fluorescens cells that protect the pathogen, enhancing its resistence against environmental constrains, such as ultraviolet radiation. This formulation was very effective in the control of Helicoverpa $z e a$ in Mexico, Honduras and EUA (17).

According to Batista Filho et al. (2), the persistence of $B t$ formulations must be considered a key factor for their sucess. The importance of the persistence increases when the pest behaviour shows certain complexity; e.g., reduced time exposure. This is the case of "bicho-furão" (Ecdytolopha aurantiana), one of the most important citrus pest in Brazil. After hatching, the larvae remain for a short period outside the fruit (4 hours), and then go inside and remain there until grow to $18 \mathrm{~mm}$ in lenght. So, the exposure of this pest to the product is reduced, hampening product ingestion. So, its necessary to know the biology of the target pest in the field to garantee that this tatic of pest management is effective.

This work provided some detailed information about persistence of Bacillus thuringiensis on maize. Further studies should be done to better elucidate the influence of intrinsic characteristics of $B t$ based products decreasing viability of a specific pest.

\section{RESUMO}

\section{Persistência de Bacillus thuringiensis em folhas de milho em condições de campo (Zea mays $\mathrm{L}$.)}

A curva de persistência de produtos à base de Bacillus thuringiensis (Bt) no campo é um importante parâmetro para avaliar a sua eficiência. A meia-vida, baseada em estimativas dos parâmetros desta curva, é um aspecto importante na seleção de pesticidas microbianos. O objetivo desta pesquisa foi estudar a relação entre a perda de viabilidade de esporos de $B t \mathrm{em}$ folhas de milho, e sua concentração, comparando-as com a persistência em campo. O delineamento experimental utilizado foi o de parcelas subdivididas no tempo, composto por plantas de milho às quais foram aplicadas três concentrações (meia dose e dose normal e dobro da dose recomendada) de uma formulação comercial de Dipel. Em cada parcela foram escolhidas ao acaso 3 folhas na parte superior de 3 plantas. Nestas, foram feitas amostragens entre 3 e 72 horas após a aplicação dos tratamentos, para contar o número de esporos viáveis, utilizandose dois discos com $1 \mathrm{~cm}$ de diâmetro. A persistência em campo foi medida com um modelo exponencial, linearizado por transformação logarítmica do número de esporos viáveis no tempo. Utilizando o método linear logarítmico dos intervalos de confiança, não foi verificada diferença significativa $(\mathrm{P}=0.05)$ nas meias-vidas em 18,2 horas para meia dose, 16,5 horas para dose normal e 13,6 horas para o dobro da dose. Considerando uma taxa fictícia de consumo de um inseto de, calculou-se as doses eficazes em cada concentração. Constatou-se que $77 \%, 78 \%$ e $80,5 \%$ das doses efetivas (esporos viáveis) permaneceram na superfície das folhas um dia após o tratamento, respectivamente.

Palavras-chave: entomopatógeno, Dipel, folha de milho, persistência no campo, Bacillus thuringiensis

\section{REFERENCES}

1. Alves, S.B.; Moraes, S.A. Quantificação de inóculo de patógenos de insetos. In: S. B. Alves (ed.), Controle Microbiano de Insetos. FEALQ, Piracicaba, 1998, p.765-778.

2. Batista Filho, A.; Alves, S.B.; Alves, L.F.A.; Pereira, R.M.; Augusto, N.T. Formulação de entomopatógenos. In: S.B. Alves (ed.). Controle Microbiano de Insetos. Piracicaba, FEALQ, 1998, p.917-966.

3. Brand, R.J.; Pinnock, D.E.; Jackson, K.L.; Milstead, J.E. Methods for assessing the field persistence of Bacillus thuringiensis spores. $J$. Invertebr. Pathol., 25, 199-208, 1975.

4. Couch, T.L.; Ignoffo, C.M. Formulation of insect pathogens. In: H. D. Burges (ed.), Microbial Control of Pests and Plant Diseases. London. Academic Press, 1981, p.621-634.

5. Dunkle, R. L.; Shasha, B.S. Strach-encapsulated Bacillus thuringiensis: a potential new method for increasing environmental stability of entomopathogens. Environ. Entomol., 17, 120-126, 1988.

6. Gallo, D.O.; Hakano, S.; Silveira Neto, R.P.L.; Carvalho, G.C.; de Baptista, E.; Berti Filho, J.R.P.; Parra, R.A.; Zucchi, S.B.; Alves, J.D.; Vendramim, L.C.; Marchini, J.R.S.; Lopes, C. Omoto Entomologia Econômica. Piracicaba, FEALQ, 2002, 649p.

7. Glare, T. R.; O'Callaghan, M. Bacillus thuringiensis: biology, ecology and safety. Chichester, John Wiley, 2000, $350 \mathrm{p}$

8. Morris, P.C.; Brice, J.H. Cereal Biotechnology. Washington, CRC Press, 2000, 352p.

9. McGuire, M.R.; Shasha, B.S. Sprayable self-encapsulation strach formulations for Bacillus thuringiensis. J. Econ. Entomol., 83, 1813 1817, 1989.

10. McGuire, M.R.; Shasha, B.S. Sprayable self-encapsulation strach formulations for Bacillus thuringiensis. J. Econ. Entomol., 89, 863869, 1996.

11. Nel, P.C.; Smit, N.S.H. Growth and development stages in the growing maize plant. Farm. South Afr., 53, 1-7, 1978.

12. Pinnock, D.E.; Brand, R.J.; Milstead, J.E. The field persistence of Bacillus thuringiensis spores. J. Invertebr. Pathol., 18: 405-411, 1971.

13. Pinnock, D.E.; Brand, R.J.; Jackson, K.L.; Milstead, J.E. The field persistence of Bacillus thuringiensis spores on Cercis occidentalis leaves. J. Invertebr. Pathol., 23, 341-346, 1974. 
14. Pinnock, D.E.; Brand, R.J.; Milstead, J.E.; Jackson. K.L. Effect of three species on the coverage and field persistence of Bacillus thuringiensis spores. J. Invertebr. Pathol., 25, 209-214, 1975.

15. Pinnock, D.E.; Brand, R.J.; Milstead, J.E.; Kirby, M.E.; Coe, N.F. Development of a model for prediction of target insect mortality following field application of a Bacillus thuringiensis formulation. J. Invertebr. Pathol., 31, 31-36, 1978.
16. Pinnock, D.E.; Brand, R.J. A quantitative approach to the ecology of the use of pathogens for insect control. In: H.D. Burges (ed.). Microbial Control of Pests and Plant Diseases 1970-1980. London, Academic Press, 1981, p.655-666.

17. Soares Júnior., G.G. New products and uses arising from Mycogen's CellCap $^{\circledast}$ biological encapsulation technology. V Simpósio De Controle Biológico, Foz do Iguaçu, 1996, p. 178-191. 